\title{
Impact of Nypa Palm (Nypa fruticans Wurmb) and Mangroves Forest on Benthic Macro Invertebrate Community in Andoni River, Nigeria
}

\author{
Emoyoma U.O. ${ }^{1}$, Numbere A.O..$^{*}$ and Woke G.N. ${ }^{1}$ \\ ${ }^{1}$ Department of Animal and Environmental Biology, University of Port Harcourt, P.M.B. 5323, \\ Choba, Nigeria
}

${ }^{*}$ Corresponding author: aroloyen@yahoo.com

Keywords: Benthic, Macro invertebrate, Nypa palm, Rhizophora, Andoni River, mangrove forest.

\begin{abstract}
It is postulated that the presence of nypa palm (Nypa palm) in mangrove forest affect the reproductive function of fish by inhibiting the growth of macro invertebrates. The impact of Nypa fruticans (Wurmb) and mangroves on the benthic macro invertebrate community of Andoni River was carried out between January and August, 2017. A total of four stations were chosen based on nypa palm and native mangrove species' presence and absence, station 1 (Open water), Station 2 (Nypa palm dominance), station 3 (Rhizophora and Avicennia dominance), Station 4 (Mixed). Results of water quality parameters include; $\mathrm{pH} 6.99 \pm 0.16$, Temperature $28.20 \pm 0.05^{\circ} \mathrm{C}$, DO $4.71 \pm 0.18 \mathrm{mg} / \mathrm{L}$, Conductivity $19.52 \pm 0.20 \mu \mathrm{m} / \mathrm{s}$, Salinity $10.76 \pm 0.07 \mathrm{ppt}$, TDS $13.45 \pm 0.27 \mathrm{ppt}$. Mean values of the physico-chemical parameters $(\mathrm{P}>0.05)$ were not significantly different. Twelve taxa of benthic macro-invertebrates in eleven families were collected. The crustaceans were more in diversity $(38.46 \%)$, while bivalvia, pisces and oligochaete had the least percentage composition (7.69\%). The gastropods were more in species dominance $(44.69 \%)$, while the Oligochaeta were least in abundance $(0.61 \%)$. Shannon Weiner's index across the stations for benthos was highest in station 2 (1.840) and lowest in station 1 (1.103). Simpson's index was highest in station 2 (1.990) and lowest in station 1 (1.938). Pielou's index of evenness was highest in station $2(0.767)$ and lowest in station 1 (0.616). All the macro-invertebrates recorded were clean water and pollution tolerant species, and showed no significant difference across stations $(\mathrm{P}>0.05)$. In conclusion this study indicates that nypa palm does not affect the proliferation of macro invertebrates, which supports fishery population along the food chain.
\end{abstract}

\section{Introduction}

Mangroves are halophytes and have evolved mechanisms for salt resistance. They provide important foraging grounds and habitats for fauna both on land and water [1]. The mixture of habitat configuration delivered by mangrove, at the margin between the land and the sea is a major cause for this. Trees comprise of conservative above-ground tree and cover habitation, and root erections within the earth or sediment, but added habitat is provided by composite root structures exceeding the soil which are often inundated by seawater. In several cases, these inundated roots support other organisms such as oysters, algae and sponges which propagate on the root tops, thereby increasing the obtainable functions of the habitat [2].

As an environment, mangroves are vital for a diversity of terrestrial, brackish and marine organisms. Many migrant birds rely on mangroves as wintering and settling sites along their traveling routes. Mangrove environment contains exclusive flora that form the precarious interface between terrestrial, estuarine, and near-shore aquatic ecosystems in humid and subtropical expanses. They defend internal anthropological populations from harm caused by coastline erosion and storms. Mangroves are well-known to deliver diverse ecological services [3], which include; a breeding ground for fish and crustaceans. 
Forest conversion involves the removal of natural forests to meet other land needs including mining of minerals, agriculture (including tree crops), and pastureland for cattle. It is a significant force driving forest disintegration and loss with relative effects on biodiversity that often involves large adjacent areas to maintain their function [4]. The development of tree crop plantations (oil palm, latex and cocoa) and the mining of gold is on the increase in the swamp forest of many West African countries owing to the overall costs of Palm oil, cocoa and gold.

Mangroves are threatened globally by pollution, tsunami, aquaculture, deforestation, hydrocarbon pollution and intrusive species. In Africa, mangroves are not only serving as refuges to flora and fauna but also function as homes to non-invasive species owing to poverty and over population. The greatest threat to the Niger-Delta mangrove is caused by crude oil exploration [5].

The mangrove ecosystem in the Niger-Delta has remained over pressured for about a century now, after the introduction, setting up and spread of Nypa palm [6, 7]. The impact of Nypa palm has been evident on the inherent mangrove macrophytes (including Rhizophora spp.). The influence of Nypa palm on intertidal benthic macro fauna has been speculated, with the assertion that it has harmfully influenced populations of these fauna in its ranges of existence [8] it is on this ground that this study was carried out.

The ability of Nypa palm to colonize areas outside its existing natural range of Indonesia has been reported from Trinidad [9], Panama [10] and West Africa [11]. Recent environmental impact assessments carried out for oil industries in the Niger delta observed that Nypa palm has invaded the mangrove areas of the Niger Delta especially the Bonny and Imo Rivers and is causing long-term ecological damage $[12,7]$.

Benthos or benthic macro-invertebrates are small marine animals and aquatic larval phases of insects such as, beetles, dragonfly, stonefly, snails, cadisfly, and crabs [13] found in coastal areas.

Macro-invertebrates of different types have different level of tolerance to contamination. They are also influenced by habitat quality. This implies that we can state the level of the habitat and quality by the composition and abundance of the resident aquatic macro-invertebrates [14]. An important aspect of biological monitoring is the use of species diversity. Diversification of organisms in biology is a dependable factor to know the health of an ecosystem [15]. The ability of macro invertebrates to be sensitive and tolerate changes in their environment has made many benthos as bio-indicators [16]. Benthos is one of the most important elements of the continental water ecosystems which can be used as indicator of water pollution, as it responds swiftly to small changes in the environment [17]. Benthic macro-invertebrate distribution is determined by sediments organic constituents and substrates.

Benthic macro-invertebrates are used often as marine ecosystem condition indicators since many benthos are pollution sensitive and abrupt alterations in their environment can affect their population. Community features including composition, richness, diversity and evenness, can be examined to know whether the community is changing over time due to natural or human-induced impacts.

Benthic invertebrate structure and composition play a major role in many aquatic researches. Importance of research on macro-invertebrates includes the easy assessment of biological resources for the conservation purpose and the detection of pollution through the dissimilarities between expected and actual fauna assemblies [18]. Benthic macro-invertebrates are recognized as indicators of water qualities. In marine environments where there are inputs from human activities, the flora of the benthic community might be adversely affected unlike in undisturbed environment. The water quality of any river will likely affect the abundance and diversity of the benthic invertebrates of the river system [19]. 
The objective of the study include: (1) To identify macro invertebrate species in different forest types i.e. mangrove forest, nypa palm forest, mixed forest and control, (2) To determine the species diversity of macro invertebrates in different forest types i.e. mangrove forest, nypa palm forest, mixed forest and control, (3) To determine the impact of mangrove and nypa palm on macro invertebrate community.

\section{Materials and Methods}

\section{Study Area}

The study area, is a section of the Andoni River (Figure 1) with a coordinate of $4^{\circ} 46^{\prime} 13.74 \mathrm{~N}$ and $7^{\circ} 28^{\prime} 6.42 \mathrm{E}$ in the Niger Delta, Nigeria, which serves as a major fish nursery [20]. The large population of fish is attributed to the abundance of mangroves within the brackish water ecosystem. The Andoni locality has a climate which consists of a short dry season from November to March and a long wet season which stretches from April to October. The area has six hours cycle of ebb and neap tides. The Andoni River is brackish water with an annual salinity range of 5- 22\%.

Four sampling stations were selected along the river course and were located at Asarama, Ngo and Okrile communities.

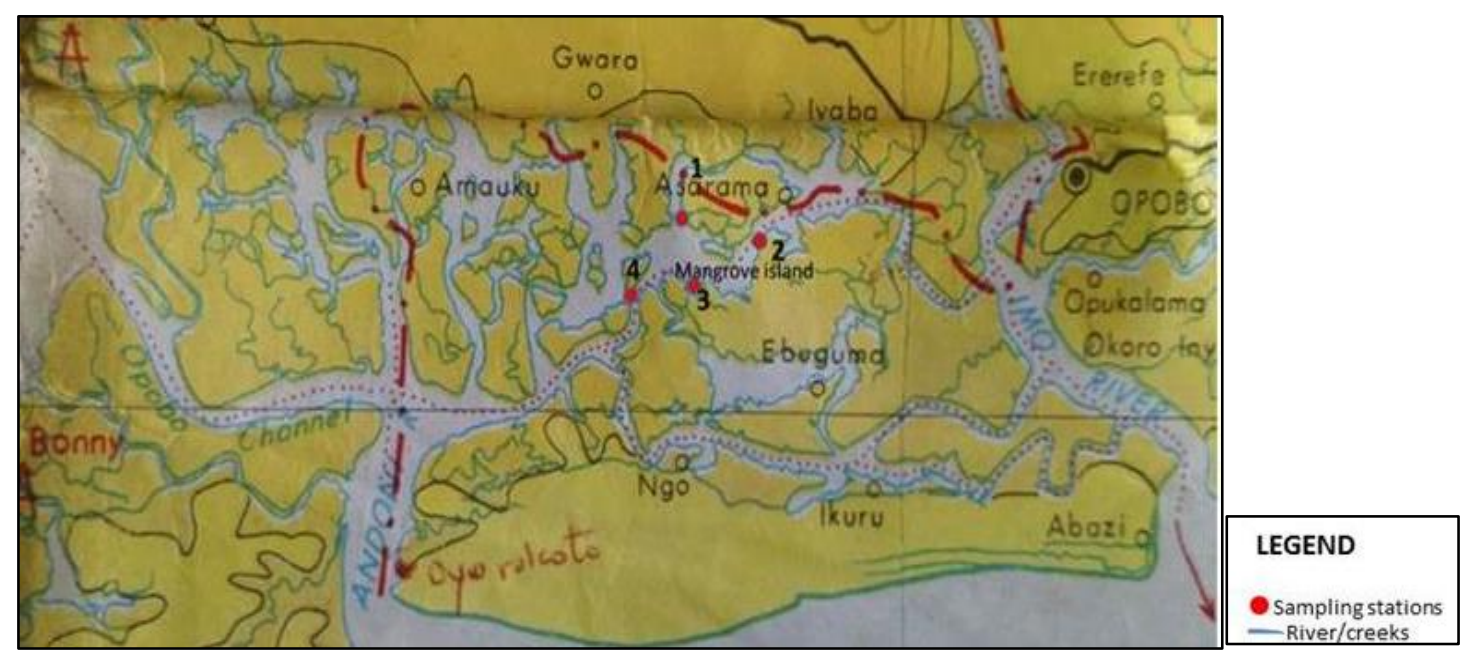

Figure 1. Map of study area indicating the area of sample collection in Andoni Local Government, Rivers State, Nigeria

\section{Delineation of study sites}

Station 1 is the control (open water), and lies between coordinates $7^{\circ} 28^{\prime} .046 \mathrm{E}$ and $04^{\circ} 30^{\prime} .838 \mathrm{~N}$ with an elevation of $14 \mathrm{~m}$. The control is the open water and chosen based on the fact that there was no vegetation in that vicinity (i.e. mangrove and nypa palm trees). It is about $4 \mathrm{~km}$ from the Asarama/Ekruta Bridge. Station 2 lies along 04 $34^{\circ} .938 \mathrm{~N}$ and $7^{\circ} 27^{\prime} .377 \mathrm{E}$ and an elevation of $8 \mathrm{~m}$ above sea level. This station is characterized by the dominance of Nypa fruticans. The station is located in Asarama about $3 \mathrm{~km}$ from the Andoni Bridge. Station 3 comprises of Ngo/Asarama Mangrove Island which lies between $7^{\circ} 27^{\prime} .262 \mathrm{E}$ and $4^{\circ} 30^{\prime} .787 \mathrm{~N}$ with an elevation of $7 \mathrm{~m}$ above sea level. This station is characterized by a high dominance of Mangroves (Rhizophora spp. and Avicenia spp.). Lastly, station 4 lies between $4^{\circ} 30^{\prime} .997 \mathrm{~N}$ and $7^{\circ} 28^{\prime} .171 \mathrm{E}$ and has an elevation of $8 \mathrm{~m}$. The station comprises of a mixture of mangroves (Rhizophora spp. and Avicenia spp.) and Nypa fruticans. Experimental design of sample location and collection pattern is illustrated in Figure 2. 


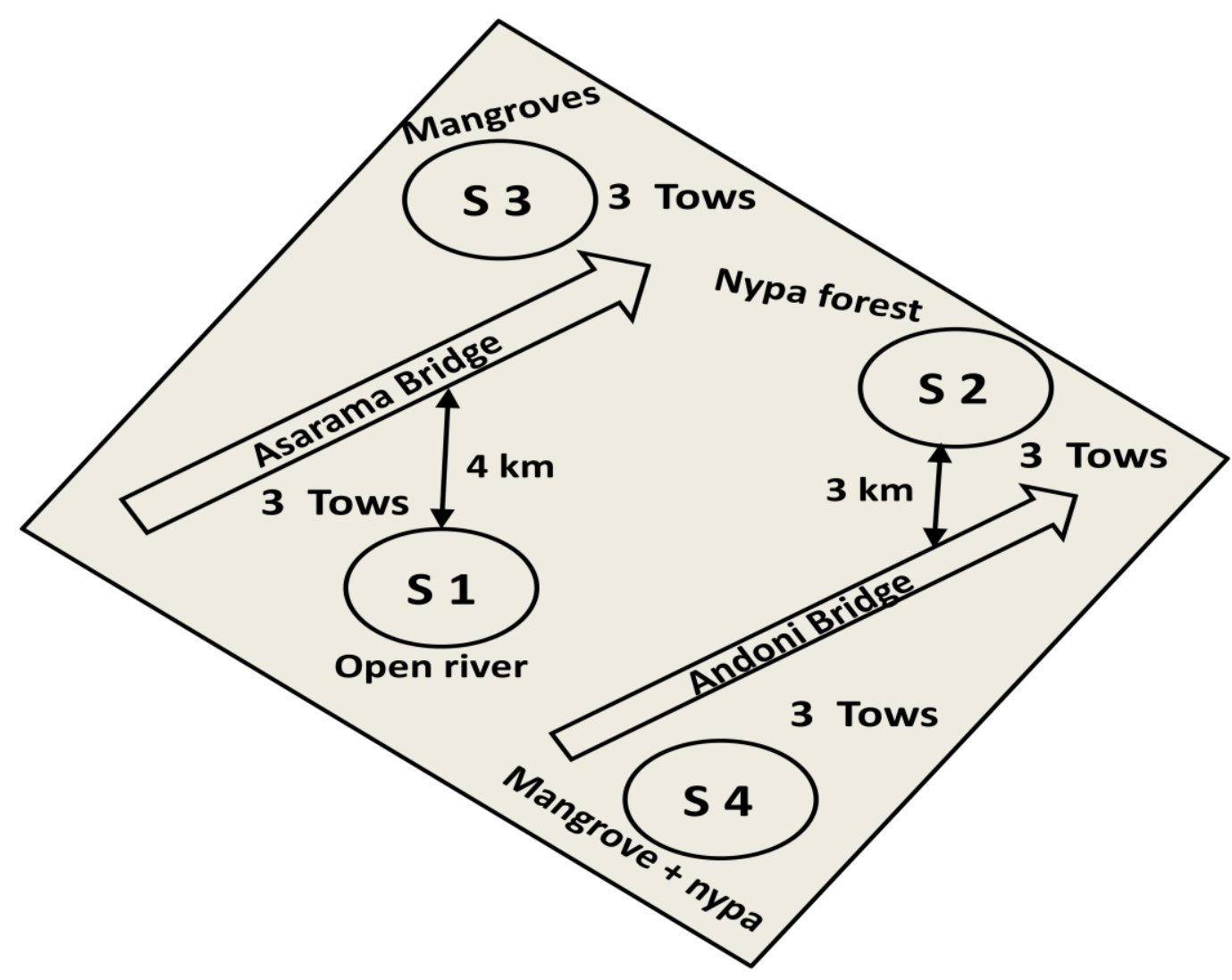

Figure 2. Experimental design of sampling along Andoni River Niger Delta, Nigeria. S1 refers to open river (control), S2 refers to Nypa pal forest, S3 refers to Mangrove forest (i.e. Rhizophora and Avicennia) and S4 refers to mixed forest (Mangrove forest + Nypa palm forest)

\section{Physico-chemical analysis}

The temperatures of the various stations were taken using mercury-in-glass thermometer. The probe was lowered into the water and temperature reading was read in-situ. The $\mathrm{pH}$, conductivity, salinity, total dissolved solids (TDS) and alkalinity were measured using Sper Scientific 86003A multi parameter meters with probes calibrated with standard solutions. Dissolved oxygen was determined by azide modification procedure (APHA-AWWA-WEF, 2012). The Winkler's method using titration technique was used to measure dissolved oxygen in fresh water system.

\section{Sampling techniques for benthic organisms}

Benthic macro-invertebrate samples were determined in the various stations from January to August 2017. Stations within the open waters were sampled using an Eckman grab of $225 \mathrm{~cm}^{3}$ operated by hand in shallow water. Stations within the inter-tidal zones where sampled using a spade. Organisms were sieved, sorted and preserved in $10 \%$ formalin and erosine. The preserved benthic macro-invertebrates samples were identified to the least taxonomic level possible using [21]. Bottom sediment samples were collected with grab at monthly intervals in polythene bags for heavy metals analysis.

\section{Statistical Analysis}

Repeated measures ANOVA was done to determine the significant difference in species number and diversity at the different stations in different months. All analysis was done in $\mathrm{R}$ environment [22]. The means and standard deviations of triplicate results were also calculated. Bar graphs were plotted to illustrate the differences. 


\section{Calculation of diversity indices}

The determination of species richness was carried out using [23] as given below:

$$
\mathrm{D}=\frac{S-1}{\operatorname{In}(N)}
$$

Where:

$\mathrm{D}=$ species richness

$\mathrm{S}=$ sum total of species

$\mathrm{N}=$ over-all number of organisms

$\mathrm{In}=$ normal logarithm $(\log \mathrm{E})$.

The community structure of the river was analyzed using the Shannon Weiner diversity index [24]. The following formula was used to calculate the diversity as follows:

$$
H=\sum P i \operatorname{InP} i
$$

Where;

$\mathrm{H}=$ Diversity in species

$\mathrm{Pi}=$ the percentage of organisms found in the $\mathrm{i}^{\text {th }}$ species.

$\mathrm{In}=$ the normal logarithm

Evenness within a community, which was used as an indication of a station's homogeneity, was calculated using Pielou's index [25] as given below:

$$
\mathrm{E}=\frac{H}{I n S}
$$

Where,

$\mathrm{H}=$ Diversity of species

$\mathrm{InS}=$ Overall number of species' natural logarithm.

\section{Results}

\section{Physico-chemistry of study environment}

Result of physico-chemistry of study environment is given in Figure 3. The lowest mean $\mathrm{pH}$ (6.28 \pm 0.23$)$ was observed in the month of March while the highest mean $\mathrm{pH}$ was observed in the month of February (7.39 \pm 0.24$)$. The temperature was lowest in the month of May with a mean value of $25.08 \pm 0.04^{\circ} \mathrm{c}$ and highest in June with a mean value of $32.7 \pm 0.07^{\circ} \mathrm{C}$. The mean salinity was observed to be lowest in the month of June with $9.83 \pm 0.03$ ppt and highest in the month January with $12.85 \pm 0.10$ ppt. The monthly dissolved oxygen was lowest in the month of April with $3.23 \pm 0.10 \mathrm{mg} / \mathrm{L}$ and highest in the month of July with $6.4 \pm 0.04 \mathrm{mg} / \mathrm{L}$. The minimum Total dissolved solids (TDS) was observed in the month of August with $8.85 \pm 0.02 \mathrm{ppm}$ while it was highest in the month of March with $18.24 \pm 0.74 \mathrm{ppm}$. The lowest mean conductivity was in the month of April with $17.68 \pm 0.05 \mu \mathrm{S} / \mathrm{cm}$ while it was highest in the month of January with $22.39 \pm 0.20 \mu \mathrm{S} / \mathrm{cm}$. Graph of monthly distribution of monthly physico-chemical parameters is given in Figure 3. 

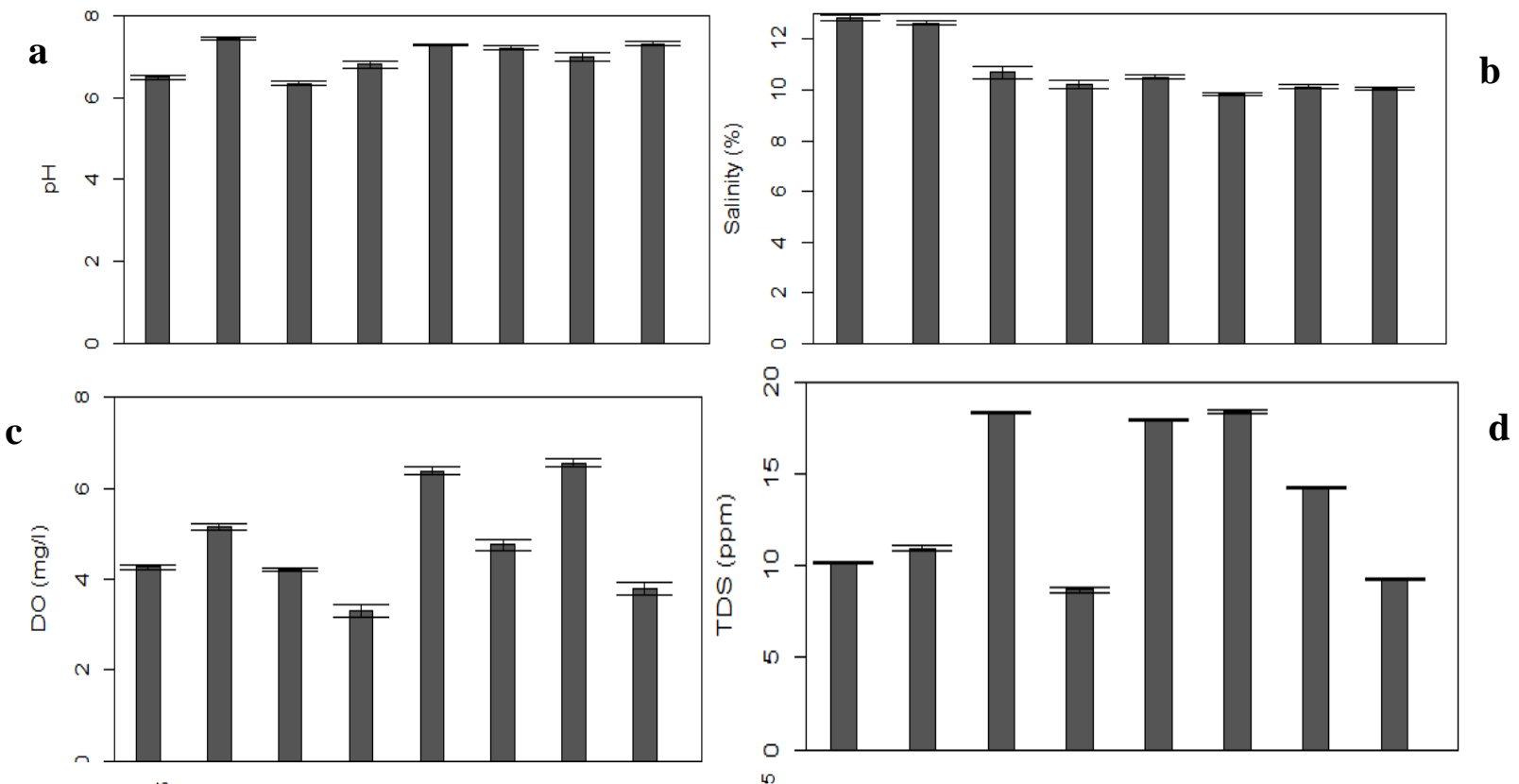

e
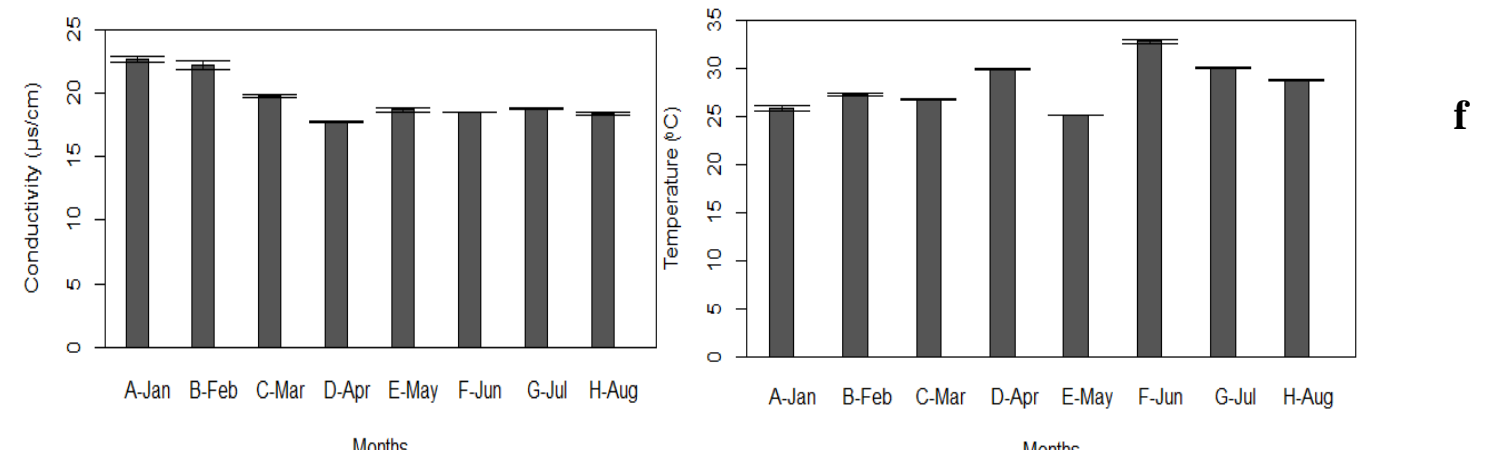

Figure 3. Mean values ( \pm SE) of monthly physico-chemistry (a) $\mathrm{pH}$, (b) salinity, (c) DO, (d) TDS, (e) conductivity and (f) temperature of study environment in Asarama, Andoni, Niger Delta Nigeria

Table 1. Range, mean and standard error of physico-chemical parameters for different stations

\begin{tabular}{ccccc}
\hline & \multicolumn{4}{c}{ Stations } \\
\cline { 2 - 5 } Parameters & 1 & 2 & 3 & 4 \\
& $($ Mean \pm SE) & Mean \pm SE & Mean \pm SE & Mean \pm SE \\
\hline pH & $6.03-7.54$ & $6.0-7.67$ & $6.3-7.66$ & $5.9-7.55$ \\
& $6.89 \pm 0.06$ & $7.18 \pm 0.07$ & $6.97 \pm 0.05$ & $6.93 \pm 0.07$ \\
Temperature $\left({ }^{0} \mathrm{C}\right)$ & $25.0-32.80$ & $25.3-32.9$ & $25.0-32.3$ & $25.0-32.8$ \\
& $28.18 \pm 0.35$ & $28.39 \pm 0.31$ & $28.06 \pm 0.33$ & $28.16 \pm 0.34$ \\
Salinity $(\% / 00)$ & $9.8-12.6$ & $9.9-13.0$ & $9.8-12.7$ & $9.7-13.3$ \\
& $10.91 \pm 0.14$ & $10.74 \pm 0.17$ & $10.72 \pm 0.15$ & $10.67 \pm 0.16$ \\
DO (mg/L) & $1.5-6.6$ & $3.0-6.3$ & $4.0-6.3$ & $3.0-6.4$ \\
& $4.46 \pm 0.23$ & $4.66 \pm 0.15$ & $4.88 \pm 0.10$ & $4.83 \pm 0.17$ \\
TDS (mg/L) & $8.92-18.24$ & $8.85-19.31$ & $8.93-21.21$ & $6.41-19.88$ \\
& $13.22 \pm 0.43$ & $13.77 \pm 0.53$ & $13.69 \pm 0.57$ & $13.13 \pm 0.65$ \\
Conductivity & $16.38-22.8$ & $17.6-23.0$ & $17.85-22.55$ & $17.45-21.34$ \\
& $19.12 \pm 0.27$ & $19.74 \pm 0.25$ & $19.83 \pm 0.26$ & $19.38 \pm 0.18$ \\
\hline
\end{tabular}




\section{Species abundance and diversity indices}

Twelve species of benthic macro invertebrates with 474 individuals which belong to 12 families and 6 classes were recorded in the study (Table 2). Station 1 (Control) had the least number of individuals (73) in seven benthic macro-invertebrate species. Station 2 (Nypa palm) and station 3 (Mangrove) recorded the highest diversities with 11 species of benthic macro-invertebrates. The mangrove dominated terrain (Station 3) recorded the highest number of individuals (174) in 11 species. Nypa palms dominated site has the highest Shannon Diversity, Simpson's and Pielou indices, followed by mangrove forest site (Table 2).

Table 2. Diversity indices of benthic macro invertebrates in Asarama, Andoni Niger Delta Nigeria

\begin{tabular}{cccccc}
\hline Stations & $\begin{array}{c}\text { Total no. of } \\
\text { organisms }\end{array}$ & no. of species & $\mathrm{H}$ & $\mathrm{S}$ & $\mathrm{J}$ \\
\hline Control & 73 & 6 & 1.103 & 1.165 & 0.616 \\
Nypa palm & 152 & 11 & 1.840 & 1.990 & 0.764 \\
Mangrove & 174 & 9 & 1.655 & 1.938 & 0.690 \\
Mixed & 75 & 7 & 1.572 & 1.621 & 0.756 \\
\hline
\end{tabular}

Where,

$\mathrm{H}=$ Shannon Weiner index of Diversity [24]

$\mathrm{S}=$ Simpson's index

$\mathrm{J}=$ Pielou's index of evenness [26].

\section{Benthic Macro invertebrate abundance}

A total of 12 taxa of benthic macro invertebrates were identified. The most dominant classes include the Annelida and Crustacea (Table 3). The Arthropods (Crustaceae) were dominant in species composition with five species in four families $(38.46 \%)$. The next most dominant was the annelids with four species. The Molluscs were represented by the Gastropoda and Bivalvia. The Pisces, Oligocheata and Bivalvia had the least representation with one species (7.69\%) each (Table 3). The Gastropods dominated in species abundance with $44.69 \%$ while the Oligochaetes had the least dominance with $0.61 \%$ (Table 4). The check list of macro invertebrates indicate that the Gastropod Tympanotomus fuscatus was the most abundant species (42.04\%) followed by the hermit crab, Clibernarius sp. (22.48\%) which was present across the stations and in all the months. Furthermore, the Oligochaeta Allonais $s p$ was the least abundant species $(0.41 \%)$ across the stations (Table 5).

Table 3. Percentage composition of families and species in each class of benthic macroinvertebrates

\begin{tabular}{ccc}
\hline Class & Total no. of families & Species composition (\%) \\
\hline Polychaeta (Annelida) & 3 & 23.08 \\
Oligochaeta (Annelida) & 1 & 7.69 \\
Crustaceae & 4 & 38.46 \\
Gastropoda & 2 & 15.38 \\
Bivalvia & 1 & 7.69 \\
Pisces (Actinopterygii) & 1 & 7.69 \\
\hline
\end{tabular}


Table 4. Percentage abundance of each class of benthic macro invertebrates

\begin{tabular}{ccc}
\hline Class & Total no. of individuals & Percentage abundance (\%) \\
\hline Polychaeta & 24 & 4.90 \\
Oligochaeta & 3 & 0.61 \\
Crustaceae & 170 & 34.69 \\
Gastropoda & 203 & 44.69 \\
Bivalvia & 30 & 6.12 \\
Pisces (Actinopterygii) & 44 & 8.98 \\
\hline
\end{tabular}

Table 5. Checklist of benthic macro invertebrates sampled from Andoni River, Nigeria

\begin{tabular}{cccc}
\hline Phylum & Class & Family & Genera \\
\hline Annelida & Polychaeta & Nereidae & Nereis succinea \\
& & Capitella & Capitella sp. \\
& Oligochaeta & Ennicidae & Marphysa sp. \\
Arthropoda & Naididae & Allonais sp. \\
& Crustaceae & Porturidae & Callinectes amnicola \\
& & Ocypodidae & Ucatangeri \\
& & Grapsidae & Sesarma aberti \\
& & & S. huzardi \\
Mollusca & Gastropoda & Clibernariusidae & Clibernarius sp. \\
& & Ellobiidae & Melampus liberianus \\
& Bivalvia & Potamididae & Tympanotomus fuscatus \\
Chordata & Ostreidae & Crassotrea gasar \\
& Pisces (Actinopterygii) & Gabiidae & Periophthalmus barbarous \\
\hline
\end{tabular}

\section{Discussion}

\section{Physico-chemistry of study environment}

The physicochemical conditions and sensitivity to environmental changes of estuarine environments are very vital in determining the composition of every aquatic flora and fauna [27]. One water quality indicator on the level of contamination of water shed is the $\mathrm{pH}$ of the water body. The $\mathrm{pH}$ result is in agreement with $[28,13]$. The $\mathrm{pH}$ range of this study (Table 1) falls within the Federal Ministry of Environment (FMENV) recommended range and also in line with previous study [21]. The $\mathrm{pH}$ is of ecological importance and has much to do with the physiology of aquatic lives.

The temperature ranges of the various stations (Table 1) were considered normal with regards to the characteristic geography of the Niger Delta which has been termed humid. An upturn in temperature will result to an increased level of chemical reactions and creation of harmful substances which may have intense influence on aquatic lives. The temperature range in this study is normal for a typical estuary. However, a range of $26.2^{\circ} \mathrm{C}-32.4^{0} \mathrm{C}$ was reported by [29]. Data on salinity showed variations between the seasons, and ranged from 9.7ppt - 13.3ppt. Mean salinity was higher in the dry season than in the rainy season. This can be attributed to the inflow of river and rainfall water. Also, higher salinity in dry season is due to the concentrating effect of the dry weather. The mean salinity recorded in Table 1 differs from that of [21] who reported higher values $11.6 \pm 0.51 \mathrm{ppt}-22.8 \pm 0.37 \mathrm{ppt}$. This can be due to the flora cover around the sampling stations, time of sampling or presence of rainfall which help attenuate the level of salinity. Salinity did not show any significant difference across the stations $(\mathrm{p}>0.05)$. 
The mean dissolved oxygen (DO) was similar across the stations. The mean dissolved oxygen range is similar to [30] who reported $3.2 \pm 0.1 \mathrm{mg} / \mathrm{L}-7.3 \pm 0.16 \mathrm{mg} / \mathrm{L}$ at Nkoro River. The solubility of oxygen is influenced basically by water temperature. This means at high temperature, oxygen level reduces while at low temperature oxygen level increases. The different stations had similar mean dissolved oxygen across the months. This can be due to similar temperature range across the stations. Dissolved oxygen did not show any significant difference across the various stations ( $>0.05$ ). Total dissolved solids (Table 1) showed no statistical significant difference $(\mathrm{p}>0.05)$. Similarly, conductivity did not show significant difference between the stations $(p>0.05)$. The highest conductivity value $(23.0 \mu \mathrm{S} / \mathrm{cm})$ was recorded at station 2 while the lowest value $(16.38 \mu \mathrm{S} / \mathrm{cm})$ was recorded at station 1 .

\section{Benthic Macro invertebrate abundance}

The result recorded in this study (Table 2) agrees with [13] who reported 14 species in Ntawogba creek but different from [31] who reported 19 species and also recorded the dominance of mollusca which was followed by Polychaete, Crustacea and Insecta. [31] reported 8 species from lower Sombreiro River of which polychaete dominated followed by crustacea, insecta, gastropoda, bivalvia and pisces. This may indicate that most water bodies in the Niger Delta consist of similar group of benthic invertebrates but with differences in abundance and species diversity. Influential factors on the distribution and abundance of invertebrates include the nature of the water body, habitat richness and stability, immediate substrate of occupation, trophic condition, partitioning and predation.

\section{Diversity indices of species}

Results from diversity indices (Table 2) adopted from Shannon Weiner's diversity index (H) and Evenness showed high values with station 1 (control) having lower diversity than stations 2, 3 and 4. The most abundant species recorded in this study was Tympanotonus fuscatus, which is in agreement with [31]. The Gastropod (Tympanotonus fuscatus) was high in abundance across the stations. Some stations had little or no representatives of the various species recorded. All sampled stations showed diversity of benthic invertebrates. Nypa palm does not adversely affect epibenthic fauna but it increases species richness through habitat heterogeneity. The highest species evenness $(0.767)$ provide shelter, traps a number of organisms and also serve as a feeding ground for many fauna.

All the macro-invertebrates recorded were clean water and pollution tolerant species. The uniformity in the distribution of these organisms could be as a result of apparent uniformity in local environmental conditions. The Andoni River generally showed the presence of common macroinvertebrate composition as in other tropical river systems. Of all benthic organisms across the various stations, the mudskipper (Periophthalmus barbarus) was the only organism recorded in stations 1 and 3, where there were no Nypa fruticans. This is in agreement with Isebor et al (2003) who reported similar scenario with little or no evidence of burrowing crabs where Nypa palm is the dominant vegetation. This can be attributed to close stands and Rhizome which inhibit their movement and productivity.

\section{Conclusion}

Based on the results from the various stations, benthic macro invertebrates were most abundant in the Mangrove (Rhizophora) dominated station (Station 3) and least abundant in the Control (Station 1). The study revealed that the diversity of the intertidal macro-benthic invertebrates of the Asarama-Andoni River was characteristically low compared to other river 
systems. The presence of Nypa fruticans did not show any differences in physico-chemical parameters. Although there is no significant difference in diversity and abundance across the stations among the benthic macro invertebrates, some species (Periophthalmus babarus) were totally absent from stations two and four where Nypa palm was present. In conclusion this study indicates that nypa palm does not affect the proliferation of macro invertebrates. Based on the outcome of the study we therefore recommend that the population of nypa palm in mangrove forest should be controlled to enhance the increase in the overall biodiversity of pelagic and benthic organisms. Future study will consider the ecosystem services of nypa palm by conducting experiment on the production of oil and wine from palms.

\section{Conflict of interest}

The author declares that there is no conflict of interest.

\section{Acknowledgement}

We want to sincerely thank Mr Otufu of the Department of Animal and Environmental Biology for assisting in identifying the species at the Hydrobiology and Fisheries Laboratory of the Department of Animal and Environmental Biology, University of Port Harcourt, Nigeria.

\section{References}

[1] M.J. Kaiser, Marine ecology: processes, systems, and impacts. (Oxford University Press, 1 (2005) 1-12.

[2] J. Hutchison, A. Manica, R. Swetnam, A. Balmford, M. Spalding, (2014). Predicting global patterns in mangrove forest biomass. Conservation Letters, 7(3) 233-240.

[3] B.A. Polidoro, K.E. Carpenter, L. Collins, N.C. Duke, E.M. Ellison, et al., The loss of species: mangrove extinction risk and geographic areas of global concern. Plos ONE, 5 (2010) e10095-e10095

[4] J.B. Long, C. Giri, Mapping the Philippines' Mangrove Forests Using Landsat Imagery. Sensors11 (3) (2011) 2972-2981.

[5] A.O. Numbere, G.R. Camilo, Reciprocal transplant of mangrove (Rhizophora racemosa) and Nypa palm seedlings in soils with different levels of pollution in the Niger Delta, Nigeria. Global Journal of Environmental Research. 10 (1) (2016) 14-21.

[6] P. Wang, A.O. Numbere, G.R. Camilo, Long term changes in mangrove landscape of the Niger River Delta, Nigeria. American Journal of Environmental Sciences, 12 (2016) 248-259. https://doi.org/10.3844/ ajessp.2016.248.259

[7] A.O. Numbere, Impact of invasive nypa palm (Nypa fruticans) on mangrove forest in the Niger Delta. In: Makowski, C; Finkl, C. (eds) coast in crisis. Coastal Research Library, vol.28. (2018) Springer, Cham.

[8] O.M. Udoidiong, A.O. Ekwu, Nipa Palm (Nypa fruticans Wurmb) and the Intertidal Epibenthic Macrofauna East of the Imo River Estuary, Nigeria. World Applied Sciences Journal 14 (9) (2011) 1320-1330.

[9] P.R. Bacon, Germination of Nypa fruticans in Trinidad. Palms, 45 (2001) 57-6I. 
[10] M.F. Castillo-Cárdenas, F. Díaz-Gonzales, I. Cerón-Souza, O. Sanjur, N. Toro-Perea, Jumping a geographic barrier: diversification of the mangrove species Pelliciera rhizophorae (Tetrameristaceae) across the Central American Isthmus. Tree genetics \& genomes, 11 (1) (2015), 82

[11] A.C. Zeven, The introduction of the Nipa palm to West Africa. Journal of the Institute of Oil Palm Research 5 (18) (1977) 35-36.

[12] SGS Environment, Nigeria LNG Project: Environment Baseline Report, Gas Transmission System, (1995).

[13] G.N. Woke, I.P. Wokoma-Aleleye, Composition and Abundance of Benthic macro invertebrate of the Nta-Wogba Creek, Port Harcourt. Global Journal of Pure and Applied Science. 13(3) (2007) 353-357.

[14] Environment Waikato, River Biology.www.ew.govt.nz. (2006) Retrieved, April, 2018.

[15] I.P. Oboh, C. S. Agbala. "Water quality assessment of the Siluko River, southern Nigeria." African journal of aquatic science 42 (2017): 279-286

[16] A.E. Ogbeibu, B.J. Oribhabor, Ecological impact of stream regulation using benthic macro invertebrates as bioindicators. Journal of Aquatic science. 16 (2001) 000-0002.

[17] K. Jenderedjian, S. Hakobyan, A. Jenderedjian, Use of Benthic Invertebrates as indicators of Pollution Origin in agricultural and Urban areas. In: Ebel A. Eds, Air, Water and soil quality modeling for Risk and Impact Assessment (2007) 217-220.

[18] M. Mauad, M.L. Miserendino, M.A. Risso, J. Massaferro, Assessing the performance of macro invertebrate metrics in the Challhuaco-Nireco System (Northern Patagonia, Argentina). Iheringia. Série Zoologia, 105(2015), 348-358.

[19] K.A. Okorafor, E.O. Effanga, A.B. Andem, U.U. George, D.I. Amos, Spatial Variation in Physical and Chemical Parameters and Macro-Invertebrates in the Intertidal Regions of Calabar River, Nigeria. Greener Journal of Geology and Earth Sciences 1 (2) (2013) 63-72.

[20] G.W. Komi, F.D. Sikoki, Physico-chemical Characteristics of the Andoni River and its potentials for production of the Giant Tiger Prawn (Penaeus monodon ) in Nigeria. Journal of Natural Sciences Research, 3(12) (2013) 83.

[21] J.M. Baker, K.A. Spokas, W.C Koskinem, Biological Monitoring - Principles, Methods and Difficulties In: Marine Ecology and Oil Pollution (Ed). The Institute of Petroleum, Great Britain. 1(2009) 41-54.

[22] R Development Core Team, R: A Language and Environment for Statistical Computing. R Foundation for Statistical Computing, Vienna Austria. http//www.R-project.org. (2018).

[23] R. Margalef, Diversity and Stability: A Practical Proposal and a Model of Interdependence. Brookhaven Symp. Biol. 20 (1967) 25-37

[24] C.E. Shannon, W. Wiener, The Mathematical Theory of Communication. University of Illnois, Press, Urban, Illnois 177p. cited by UNESCO 1991: Manual on Marine Experimental Ecosystem UNESCO Tech. Papers in Marine Science 61 (1963) 1-6.

[25] E.C. Pielou, An Introduction to Mathematical Geology. Wiley-Inter science New York, (1969) 289 p. 
[26] F.O. Arimoro, C.M. Iwegbue, O. Osiobe, Effect of Industrial waste water on the physical and chemical characteristics of Warri River, a coastal water body in the Niger Delta, Nigeria. Research Journal of Environ Science 2 (2008) 209-20.

[27] N. Zabbey, F.O. Arimoro, Environmental forcing of intertidal benthic macrofauna of Bodo Creek, Nigeria: Preliminary index to evaluate cleanup of Ogoniland. Regional Studies in Marine Science, 16 (2017), 89-97.

[28] E.J. Ansa, F.D. Sikoki, A. Francis, M.E. Allison, Seasonal variation in interstitial fluid quality of the Andoni flats, Niger Delta Nigeria. Journal of Appl. Sci. Environ. Manage. 11(2) (2007) 123-127.

[29] J.F.N. Abowei, Salinity, dissolved oxygen, $\mathrm{pH}$ and surface water temperature conditions in Nkoro River, Niger Delta, Nigeria. Advance Journal of Food Science and Technology. 2 (2010) 36-40.

[30] J.O. Olomukoro, C.N. Azubuike, Heavy Metals and Macro invertebrate communities in bottom sediment of Ekpan creek, Warri, Nigeria. Jordan Journal of Biological Sciences, 2 (2009) 1.

[31] O.A.F. Wokoma, N. Umesi, (2017). Benthic Macro-Fauna Species Composition and Abundance in the Lower Sombreiro River, Niger Delta, Nigeria. European-American Journal 1 (2017) 17-23. 